\title{
Factors associated with falls in elderly people with osteopenia or osteoporosis counter-referred from secondary care
}

\author{
Fernanda Campos PINHEIRO, Edna Afonso REIS, Cristina Mariano RUAS \\ Faculdade de Farmácia da Universidade Federal de Minas Gerais \\ Corresponding author: Pinheiro FC, fecapinheiro@gmail.com
}

Submitted: 27-09-2019, Resubmitted: 23-01-2020, Accepted: 28-01-2020

Peer review: blind reviewers

\begin{abstract}
Objective: Analyze the factors associated with the occurrence of falls in the elderly with low bone mineral density. Methods: Study performed between July 2014 and January 2016. Involved a cross sectional secondary data collection and telephone survey to counterreferred elderly patients from a secondary care service for primary care service in Belo Horizonte, Minas Gerais. Results: Were analyzed data from 2.020 patients and, among them, 1.120 were selected to participation in telephone survey phase. Respondents were predominantly female, aged 70-79 years, with normal or overweight body mass index, diagnosed with osteoporosis and family history of fractures. Regarding habits, the greater proportion did not practice physical activities, did not drink and smoke, did not sunbathe and had low intake of dark green vegetables. In addition, most of them had a fixed income, had been contacted by primary care after counterreferral and depended exclusively on the National Unified Health System. Higher proportion of falls was observed among women, in patients diagnosed with osteoporosis, with advanced age, who did not receive contact to return to the health center and in those with individual and family history of fractures. Statistical analysis demonstrate female gender, advanced age, individual or family history of fractures and low or no intake of dark green vegetables were factors that increased the risk of falls. Conclusion: Recommendations for improving health habits are simple actions and should be encouraged because they contribute to reducing the occurrence of falls and, consequently, it may lead to decrease morbidity and mortality of elderly patients.
\end{abstract}

Keywords: osteoporosis, bone density, accidental falls, health services for the aged, epidemiologic research design, healthcare surveys.

\section{Fatores associados à ocorrência de quedas em idosos com osteopenia e osteoporose contrarreferenciados pela atenção secundária}

\begin{abstract}
Resumo
Objetivos: Analisar os fatores associados à ocorrência de quedas em idosos com baixa densidade mineral óssea. Métodos: Estudo realizado entre julho de 2014 e janeiro de 2016. Envolveu um corte transversal com coleta de dados secundários e inquérito telefônico a idosos com baixa densidade mineral óssea contrarreferenciados de um serviço de atenção secundária para a atenção primária em Belo Horizonte, Minas Gerais. Resultados: Dados de 2.020 pacientes foram analisados e, dentre eles, 1.120 participaram da fase de inquérito telefônico. Os entrevistados eram predominantemente do sexo feminino, com idade entre 70-79 anos, apresentavam Índice de Massa Corporal classificado como normal ou com sobrepeso, com diagnóstico de osteoporose e histórico familiar de fraturas. Quanto aos hábitos, maior proporção não praticava atividades físicas, não bebia e não fumava, não tomava banho de sol e tinha baixa ingestão de verduras verde-escuro. Além disso, em sua maioria, possuía renda fixa, havia sido contatado pela atenção primária após contrarreferenciamento e dependia exclusivamente do Sistema Único de Saúde. Maior proporção de quedas foi observada entre mulheres, em pacientes com diagnóstico de osteoporose, com faixa etária avançada, que não receberam contato para retorno ao centro de saúde e naqueles com histórico individual e familiar de fraturas. Análise estatística demonstrou que sexo feminino, faixa etária avançada, histórico individual ou familiar de fraturas e baixa ou nenhuma ingestão de verduras de coloração verde escuro foram fatores que aumentaram o risco de quedas. Conclusão: Ações simples como recomendações para melhoria dos hábitos de saúde devem ser fomentadas, pois contribuem para a redução da ocorrência de quedas e, consequentemente, podem levar à diminuição da morbimortalidade dos pacientes idosos.
\end{abstract}

Palavras-chave: osteoporose, densidade óssea, saúde do idoso, acidentes por quedas, planos e programas de saúde, projetos de pesquisa epidemiológica, inquéritos epidemiológicos. 


\section{Introduction}

With the increasing life expectancy of the Brazilian population, ${ }^{1}$ health professionals have turned their attention to the problems inherent to aging, such as chronic diseases, the continuous use of medication and the fragility and risks involving all these factors, of which the most important is the occurrence of falls. ${ }^{2}$

Several studies indicate that approximately one-third of the elderly population aged 65 and over experience an annual episode of fall. ${ }^{2}$ This event has assumed an epidemic dimension in the Brazilian elderly population, representing an important cause of morbidity and mortality due to the great susceptibility to injuries and their consequences. ${ }^{3}$ Data from the Ministry of Health ${ }^{4}$ show that about $30 \%$ of the elderly fall each year; this rate rises to $40 \%$ among the elderly over 80 and to $50 \%$ among those living in long-term care institutions for elderly people. These data also indicate that women tend to fall more frequently when compared to men up to the age of 75 , but that the frequencies are equal from that age onwards.

Risk factors for falls are well established, and the main one is associated with osteoporosis. $.3,5,6,7$ In Brazil, in 2010, the cost of treatment and assistance by the SUS for the care of patients with osteoporosis and victims of falls and fractures was approximately 81 million reais. ${ }^{8}$

In the state of Minas Gerais, there is a project called "Programa Mais Vida" ("More Life Program") the referral of the elderly to specialized secondary care services, so that they can be evaluated by a multidisciplinary health team, aiming to improve their quality of life and to integrate the care provided to the elderly patient. At the end of the process, patients are counter-referred to primary care with a care plan that suggests treatments and measures to improve quality of life, including the prevention of falls and fractures.

Considering the risks involved in fractures in the elderly and the existence of a public health program specialized in the care of this age group, it becomes opportune to know the profile of the patients attended and the health actions involved in the prevention and treatment of osteoporosis. The objective of this research, therefore, is to analyze the factors associated with the occurrence of falls in elderly people with low bone mineral density.

\section{Methods}

This is a cohort carried out at two different times: I. Data collection from the patients in a secondary source; and, II. Telephone survey. Patients considered to be frail elderly cared for by primary health care in Belo Horizonte city, were referred to secondary care where a multidisciplinary care plan was established, which should be implemented by primary care, after counter-referral.

In the first phase, data from these care plans were used and sent electronically to the basic health units. In the second phase, the same patients were contacted by telephone. The telephone questionnaire was made based on the methodology of telephone surveys already carried out in Brazil, such as Vigitel ${ }^{10}$, and the questions and answer options were defined by consensus among specialists and researchers.

The inclusion criteria for the study were the following: patients diagnosed with osteopenia or osteoporosis who had been cared for at least one year ago in specialized care; aged 60 or older; who responded to the telephone survey; and with records related to the occurrence of falls.
Data collection in the first phase was carried out directly from the history of e-mails sent by the secondary care institution between September 2011 and December 2013. The interviews took place between July 2014 and January 2016. The two stages were executed by undergraduate and graduate students, previously trained.

Besides the dependent variable of occurrence of falls (yes/ no) in the year preceding the telephone survey, independent variables were collected: sociodemographic: receiving a monthly fixed income (yes/no), access to a private health plan or insurance (yes/no); anthropometric: gender (male/female), age range, Body Mass Index (BMI) classification; clinical: general densitometric diagnosis (osteopenia/osteoporosis), individual fracture history (yes/no), family history of fractures (yes/no), previous or current smoking (yes/no), previous or current alcohol use (yes/no); lifestyle-related: physical activity (yes/no), daily intake of milk and/or dairy products (yes/no), frequency of dark green vegetable intake (medium or high/none or low), frequency of sunbathing (medium or high/none or low); and related to the use of medication for the prevention or treatment of osteoporosis (yes/no). The daily intake of milk referred to the minimum amount of a portion of milk or its derivatives ingested each day. Regarding the frequencies in the intake of calcium-rich vegetables (dark green leafy vegetables) and sunbathing, they were considered as medium or high when they occurred three times or more per week, while physical activity was considered regular when it was performed at least twice a week. The family history of fractures concerned hip fractures in first-degree relatives, in this case, the patient's father or mother.

A descriptive analysis of the data was performed, with the calculation of absolute and relative frequencies in all the variables. The characteristics of the patients were compared according to the occurrence or not of falls, using the Chi-square test. The variables that presented statistically significant association $(p<0.20)$ with the occurrence of falls were selected for the binary logistic regression model. The variables in the final model were selected by the stepwise method $(p<0.05)$. The quality of the logistic regression model setting was evaluated by Hosmer-Lemeshow test with $p>0.05$ and the area below the ROC (Receiver Operating Characteristics) curve greater than 0.60 . In the occurrence of falls, the magnitude of the effect of the variables in the final model was calculated by means of the estimates of the Odds Ratio, with a 95\% confidence interval.

The data were compiled into tables in the Microsoft Excel 2010 software and analyzed using the Minitab statistical application, version 17.3.1.

The research was approved by the Ethics and Research Committee of the Federal University of Minas Gerais, under No. 534337.

\section{Results}

Of the 2,020 selected patients in the first phase, 1,268 (62.8\%) had eligible telephonic lines and participated in the telephonic survey. 121 deaths were observed, and 27 patients refused to participate in the survey; in the end, 1,120 telephonic surveys were made. Five patients were excluded for not having any falls occurrence records. The population of this study was of 1,115 patients (Figure 1). 
Figure 1. Flow chart for the selection of the study population.

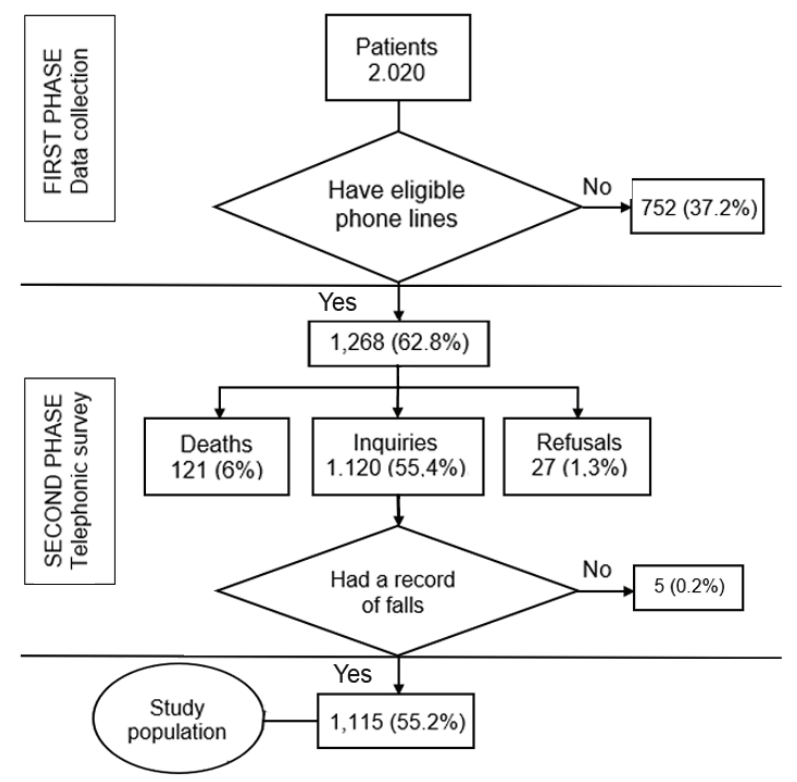

The participants were predominantly female $(81.8 \%)$ and the mean age of the patients was 75.7 years old, ranging from 60 to 96 . The mean BMI was $26.2 \mathrm{~kg} / \mathrm{m}^{2}$ and ranged from 12.4 to $45.0 \mathrm{~kg} / \mathrm{m}^{2}$. The diagnosis of osteoporosis was more prevalent $(51.9 \%)$ than osteopenia (48.1\%). Most of the patients had a fixed income (94.5\%), no health plan (83.4\%), and had been contacted by the basic health unit after the counter-referral (91.4\%). Regarding life habits, the majority did not practice physical activities (85.3\%), ingested milk or dairy products daily $(84.5 \%)$, had a low or no dark green vegetable intake (54.5\%), and did not sunbathe or did it at low frequency (77.7\%). As for the fractures, $41.0 \%$ had an individual history and $90.9 \%$ had a family history of fractures. As for the smoking or drinking habits, $10.4 \%$ were current or former smokers and $11.8 \%$ were current or former alcohol users. Of the total number of patients, $56.8 \%$ were undergoing pharmacological treatment (Table 1).

Regarding the occurrence of falls in the year before the interview, $30.9 \%$ of the patients reported having suffered at least one. Among these, $2.9 \%$ reported repeated falls within the time interval considered. Comparing the elderly who fell with those who did not, there was a higher proportion of falls among women, diagnosed with osteoporosis, with individual and family history of fractures, and the differences were statistically significant (Table 1).

Table 1. Comparison between the occurrence or not of falls, according to sociodemographic, anthropometric, clinical and lifestyle characteristics, in elderly patients with low bone mass counter-referred by secondary care to primary care. Belo Horizonte, $2011-2016$

\begin{tabular}{|c|c|c|c|c|c|c|c|}
\hline \multirow{3}{*}{ Characteristics } & \multirow{2}{*}{\multicolumn{2}{|c|}{$\begin{array}{l}\text { General }^{(1)} \\
(\mathrm{N}=1,115)\end{array}$}} & \multicolumn{4}{|c|}{ Occurrence of falls ${ }^{(2)}$} & \multirow{3}{*}{$\mathbf{p}^{(3)}$} \\
\hline & & & \multicolumn{2}{|c|}{ No $(\mathrm{N}=771)$} & \multicolumn{2}{|c|}{ Yes $(\mathrm{N}=344)$} & \\
\hline & $\mathrm{n}$ & $\%$ & n & $\%$ & $\mathrm{n}$ & $\%$ & \\
\hline Female gender ${ }^{(4)}$ & 912 & 81.8 & 614 & 79.6 & 298 & 87.4 & 0.005 \\
\hline Age Group (years old) & & & & & & & 0.188 \\
\hline $60-69$ & 233 & 20.9 & 169 & 21.9 & 64 & 18.6 & \\
\hline $70-79$ & 521 & 46.7 & 354 & 45.9 & 167 & 48.5 & \\
\hline $80-89$ & 338 & 30.3 & 236 & 30.6 & 102 & 29.7 & \\
\hline $90+$ & 23 & 2.1 & 12 & 1.6 & 11 & 3.2 & \\
\hline BMI classification & & & & & & & 0.169 \\
\hline Low weight & 33 & 3.0 & 23 & 3.0 & 10 & 2.9 & \\
\hline Adequate & 416 & 37.7 & 289 & 38.0 & 127 & 37.2 & \\
\hline Overweight & 412 & 37.4 & 296 & 38.9 & 116 & 34.0 & \\
\hline Obese & 241 & 21.9 & 153 & 20.1 & 88 & 25.8 & \\
\hline Densitometric diagnosis & & & & & & & 0.046 \\
\hline Osteopenia & 536 & 48.1 & 386 & 50.1 & 150 & 43.6 & \\
\hline Osteoporosis & 579 & 51.9 & 385 & 49.9 & 194 & 56.4 & \\
\hline Has a monthly income $e^{(4)}$ & 1,052 & 94.5 & 730 & 94.7 & 322 & 94.2 & 0.720 \\
\hline Has a health plan ${ }^{(4)}$ & 185 & 16.6 & 124 & 16.1 & 61 & 17.7 & 0.500 \\
\hline Received contact for returning to the health center ${ }^{(4)}$ & 1,014 & 91.4 & 709 & 92.4 & 305 & 89.2 & 0.073 \\
\hline Practices physical activity ${ }^{(4)}$ & 164 & 14.7 & 117 & 15.2 & 47 & 13.7 & 0.510 \\
\hline Drinks milk daily $y^{(4)}$ & 940 & 84.5 & 659 & 85.6 & 281 & 81.9 & 0.120 \\
\hline Frequency in the intake of dark green vegetables & & & & & & & 0.051 \\
\hline Medium/High & 502 & 45.4 & 363 & 47.3 & 139 & 41.0 & \\
\hline Low/None & 604 & 54.6 & 404 & 52.7 & 200 & 59.0 & \\
\hline Sunbathing frequency & & & & & & & 0.420 \\
\hline Medium/High & 249 & 22.3 & 167 & 21.7 & 82 & 23.8 & \\
\hline None/Low & 866 & 77.7 & 604 & 78.3 & 262 & 76.2 & \\
\hline Individual history of fractures ${ }^{(4)}$ & 457 & 41.0 & 276 & 35.8 & 181 & 52.6 & $<0.001$ \\
\hline Presence of family history of fractures ${ }^{(4)}$ & 84 & 9.1 & 48 & 7.4 & 36 & 13.1 & 0.006 \\
\hline Smoker or ex-smoker ${ }^{(4)}$ & 116 & 10.4 & 76 & 9.9 & 40 & 11.7 & 0.358 \\
\hline Present or previous alcohol consumption ${ }^{(4)}$ & 131 & 11.8 & 87 & 11.3 & 44 & 12.9 & 0.453 \\
\hline Pharmacological treatment ${ }^{(4)}$ & 619 & 56.8 & 425 & 56.4 & 194 & 57.7 & 0.690 \\
\hline
\end{tabular}

Note: The total values differ among the different patient characteristics due to the missing data. (1) The percentages add up to $100 \%$ in the column. (2) The percentages add up to $100 \%$ in the column. (3) Chi-square test. (4) Variable with a binary answer of the yes or no type. The proportions are given for the "yes" answers.Source: Elaborated by the author, based on the database of the project entitled "Clinical and epidemiological aspects of patients submitted to osteometabolic evaluation at the CMV of the Jenny Faria Institute for the Health Care of Elderly Individuals and Women". ${ }^{5}$ 
To evaluate the factors associated with the occurrence of falls, it was necessary to exclude the missing data (19.4\%), obtaining a total of 899 records. It was observed that being male and not having an individual or family history of fractures were protective factors against the occurrence of falls. Low or no intake of dark green colored vegetables and advanced age groups were factors that increased the chance of falls. The individual history of fractures showed a strong positive association since the elderly who already had a fracture would have 2.3 times more chance to fall than the one who never suffered any fracture (Table 2).

Table 2. Multiple associations between the socio-demographic and clinical characteristics and the occurrence of falls in elderly patients with low bone mass counter-referred by secondary care to primary care. Belo Horizonte, 2011-2016

\begin{tabular}{|c|c|c|c|c|c|}
\hline Term & Coefficient & SE & OR & $(95 \% \mathrm{Cl})$ & $\mathbf{p}$ \\
\hline Constant & -0.288 & 0.186 & & - & $<0.001$ \\
\hline \multicolumn{6}{|l|}{ Gender } \\
\hline Female & - & - & & - & - \\
\hline Male & -0.587 & 0.219 & 0.5562 & $(0.3620 ; 0.8545)$ & 0.007 \\
\hline \multicolumn{6}{|l|}{ Age group } \\
\hline $60-69$ & - & - & & - & - \\
\hline $70-79$ & 0.281 & 0.197 & 1.3241 & $(0.8991 ; 1.9499)$ & 0.155 \\
\hline $80-89$ & 0.019 & 0.217 & 1.0191 & $(0.6664 ; 1.5584)$ & 0.931 \\
\hline $90+$ & 0.581 & 0.581 & 2.7448 & $(0.8790 ; 8.5712)$ & 0.082 \\
\hline \multicolumn{6}{|c|}{ Frequency in the intake of dark green vegetables } \\
\hline Medium/High & - & - & 0.6903 & $(0.5099 ; 0.9345)$ & - \\
\hline Low/None & 0.371 & 0.155 & & - & 0.016 \\
\hline Individual history of fractures ${ }^{(4)}$ & - & - & 2.2547 & $(1.6729 ; 3.0388)$ & $<0.001$ \\
\hline Family history of fractures ${ }^{(4)}$ & - & - & 1.5650 & $(0.9680 ; 2.5302)$ & 0.068 \\
\hline
\end{tabular}

Nota: EP: erro padrão dos coeficientes, OR: Odds Ratio (razões de chances), IC95\%: intervalo de confiança de 95\%. Teste de Hosmer-Lemeshow: p=0,337; área abaixo da cuva ROC $A \cup C=0,66$. (4) Variável com resposta binária do tipo sim ou não. Apresentadas as proporções para as respostas "sim". Fonte: Elaboração da autora, com base no banco de dados do projeto "Aspectos clínicos e epidemiológicos de pacientes submetidos à avaliação osteometabólica no CMV do Instituto Jenny Faria de Atenção à Saúde do Idoso e da Mulher"

The quality of the proposed model was verified by the HosmerLemeshow test $(p=0.337)$ and the calculated area below the ROC curve equal to $A \cup C=0.66$, indicating an acceptable discrimination capacity.

\section{Discussion}

The literature indicates that approximately one-third of the elderly population experiences an annual fall episode, corroborating with the results of this study. ${ }^{2}$ Other Brazilian research studies that evaluated the occurrence of falls in elderly people observed similar values: a study conducted with the elderly population of 23 Brazilian states observed a prevalence of falls in $27.6 \%$ of the interviewees. ${ }^{11}$ Another study conducted in Juiz de Fora/MG reported falls in $32.1 \%$ of the elderly individuals, ${ }^{12}$ whereas in a cohort one conducted in São Paulo falls were observed in 31.0\%. ${ }^{13}$ More recently, a survey conducted in Santa Catarina showed a prevalence of falls in $28.3 \%$ of the sample of elderly individuals. ${ }^{14}$

The statistical analysis showed a positive association between falls and the female gender. Several national and international studies associate falling with the female gender, but the causes are not yet clearly defined. ${ }^{11,12,15}$ This fact may be related to greater bone and muscle fragility in women and, consequently, to a greater susceptibility to falls. In a cross-sectional study, a predominance of falls was observed in elderly women, with a prevalence for those who were exclusively dedicated to taking care of the household chores. ${ }^{16}$ It can be suggest that the causes may also be related to longer life expectancy and increased exposure of women to environmental risks. ${ }^{5,13}$

The bio-availability of calcium from leafy vegetables is quite high, and several studies report a positive association between the consumption of these foods and the increase in bone mineral density. ${ }^{17-19}$ A cohort conducted in Australia has shown that vegetable intake is beneficial for reducing the risk of falls in elderly women; however, the limitation on the measurement of the quantity of food in this research is recognized. ${ }^{23}$ Nutritional studies with validated techniques could establish more robust relationships for the understanding of this factor. It could be observed in this study that the ingestion of dark green vegetables had a negative association with the occurrence of falls. Vegetable intake, in general, denotes healthy eating and international studies conducted in the Netherlands and Australia relate the occurrence of falls to the nutritional factor. ${ }^{20,21}$ Nutrition, fundamental to maintaining health, is strictly related to habits and lifestyle, which change over the years. If these habits are not well adapted, they can bring about consequences related to the loss of strength and resistance, such as sarcopenia and osteoporosis. ${ }^{22}$ Several factors can interfere with the eating habits of each elderly person, such as loss of teeth, financial limitations, need for help with food preparation and morbidities that affect mood and the digestive system and can decrease appetite and taste, creating an unfavorable scenario for a healthy diet. ${ }^{22}$ In many cases, the care plan elaborated for counter-referencing suggests the supplementation of calcium through food, and the patient receives detailed guidance from a nutritionist of the multidisciplinary team to adapt his or her routine and that of their relatives, a fact that may have contributed to the data found.

This study observed a positive association between the history of fractures and the occurrence of falls, a fact that has already been demonstrated in the literature. A study conducted with elderly community residents observed that a history of bone fractures can increase the chance of falling by almost eight times and signaled that, if this fracture was the result of a fall, the elderly become more vulnerable to further episodes. ${ }^{13}$

The differential of this study is the population, consisting of elderly men and women with a defined diagnosis of low bone mass, while most of the research studies deal with post-menopausal women without a previous diagnosis. The collection of these data becomes important to characterize the group in question and to favor the planning and evaluation of the health services. 
For its economic and technical feasibility, telephone interviews are recommended for data collection in research and as a strategy for monitoring the health conditions of several populations. ${ }^{24}$ However, it should be considered that many respondents may have had difficulty in remembering certain data at the risk that some responses do not correspond to reality. One limitation of this study is that the number of lost (missing) data varied according to the explanatory variables, but the size of the population helped to circumvent this occurrence.

\section{Conclusion}

The patients counter-referred from secondary care to the Health Centers were women, aged 70-79, with a BMI classified as normal or overweight, with a diagnosis of osteoporosis and a family history of fractures. As for the habits, a greater proportion did not engage in physical activity, did not drink or smoke, did not sunbathe and had a low intake of dark green vegetables. Moreover, most of them had a fixed income, had been contacted by primary care after counter-referral and depended exclusively on the SUS. A higher prevalence of falls was observed in women, in patients diagnosed with osteoporosis and in those with individual or family history of fractures. The statistical analysis showed that being male and not having an individual or family history of fractures were protective factors for the occurrence of falls, while the advanced age range was a factor that showed an increased chance of falling. It could also be observed that the ingestion of calcium-rich vegetables can be beneficial in reducing the risk of falls.

\section{Funding sources}

Foundation for Research Support of Minas Gerais (Fundação de Amparo à Pesquisa de Minas Gerais, FAPEMIG).

Project: Clinical and epidemiological aspects of patients submitted to osteometabolic evaluation at the Jenny Faria Institute for the Health Care of Elderly Individuals and Women. Via edict (direct mode), number APq-00760-14.

Beneficiary: Cristina Mariano Ruas - Federal University of Minas Gerais.

Value: $\mathrm{R} \$ 16,401.21$

\section{Collaborators}

All the authors have contributed to this work. Pinheiro FC: participated in all the phases of the project: conception of the research project, data analysis and interpretation, writing and critical review. Ruas CM: participated in all the phases of the project: conception of the research project, data analysis and interpretation, writing and critical review. Reis EA: participated in the phase of data analysis and interpretation, and in the critical review. They all make public their responsibility for the content.

\section{Conflict of interest statement}

The authors declare that there are no conflicts of interest regarding this article.

\section{References}

1. Brasil. Instituto Brasileiro de Geografia e Estatística (IBGE). Censo Demográfico 2010. Rio de Janeiro (RJ): IBGE; 2011. Available from https://ww2.ibge.gov.br/home/estatistica/ populacao/censo2010. Accessed on10 Nov 2018.

2. Coutinho ESF, Bloch K, Coeli CM. Mortalidade em um ano de idosos após hospitalização por fratura decorrente de queda: comparação com idosos pareados da população. Cad. Saúde Pública. 2012 Apr;28(4):801-05.

3. Moraes EN, Moraes FL. Avaliação multidimensional do idoso, 4. ed. Belo Horizonte: Folium; 2014.

4. Brasil. Ministério da Saúde. Cadernos de Atenção Básica: Envelhecimento e saúde da pessoa idosa. Brasília: Ministério da Saúde; 2007.

5. Brito FC, Costa SMN. Quedas. "In": Netto MP, Brito FC (ed). Urgências em geriatria, 1. ed. São Paulo: Atheneu; 2001:32335.

6. Fuchs FD, Wannmacher L, Ferreira MBC. Farmacologia clínica: Fundamentos da terapêutica racional, 4. ed. Rio de Janeiro: Guanabara Koogan; 2010.

7. Rubinstein LZ. Falls in older people: epidemiology, risk factors and strategies for prevention. Age Ageing. 2006 Sep;35(2):ii37-ii41.

8. Rosa P. Prevenção à osteoporose deve começar na infância. Available from http://portalsaude.saude.gov.br/index.php/ cidadao/principal/saude-em-dia/mais-sobre-saude-em-dia. Accessed on 05 mar 2016.

9. Minas Gerais, Secretaria de Estado de Saúde. Resolução SES 2.603 de 7 de dezembro de 2010. Dispõe sobre o Programa Mais Vida - Rede de Atenção à Saúde do Idoso de Minas Gerais, e dá outras providências. Belo Horizonte: Secretaria de Estado de Saúde, 2010.

10. Brasil. Ministério da Saúde. Vigitel Brasil 2012: Vigilância de fatores de risco e proteção para doenças crônicas por inquérito telefônico. Brasília: Ministério da Saúde; 2013.

11. Siqueira FV, Facchini LA, Silveira DS, et al. Prevalência de quedas em idosos no Brasil: uma análise nacional. Cad. Saúde Pública. 2011 Sep;27(9):1819-26.

12. Cruz DT, Ribeiro LC, Vieira MT, et al. Prevalência de quedas e fatores associados em idosos. Rev Saúde Pública. 2012 Feb;46(1):138-46.

13. Perracini MR, Ramos LR. Fatores associados a quedas em uma coorte de idosos residentes na comunidade. Rev Saúde Pública. 2002;36(6):709-16.

14. Gullich I, Cordova DDP. Queda em idosos: estudo de base populacional. Rev Soc Bras Clin Med. 2017 Out-Dez;15(4):230-4.

15. Silva A, Faleiros HH, Shimizu WAL, et al. Prevalência de quedas e de fatores associados em idosos segundo etnia. Ciênc. saúde coletiva. 2012;17(8):2181-90.

16. Oliveira KA, Rodrigues CC, Ribeiro RCHM, et al. Causas de traumas em pacientes idosos atendidos em unidade de emergência. Rev enferm UFPE on line. 2013 Apr;7(4):111319.

17. Byberg L, Bellavia A, Orsini N, et al. Fruit and vegetable intake 
and risk of hip fracture: a cohort study of Swedish men and women. J Bone Miner Res. 2015 Jun;30(6):976-84.

18. Xie $\mathrm{HL}, \mathrm{Wu} B \mathrm{BH}, \mathrm{Xue} W \mathrm{~W}$, et al. Greater intake of fruit and vegetables is associated with a lower risk of osteoporotic hip fractures in elderly Chinese: a 1:1 matched case-control study. Osteoporos Int. 2013 Nov;24(11):2827-36.

19. Benetou $V$, Orfanos $P$, Feskanich $D$, et al. Fruit and vegetable intake and hip fracture incidence in older men and women: The CHANCES project. J Bone Miner Res. 2016 Sep;31(9):1743-52.

20. Neyens J, Halfens R, Spreeuwenberg $M$, et al. Malnutrition is associated with an increased risk of falls and impaired activity in elderly patients in Dutch residential long-term care (LTC): a cross-sectional study. Arch Gerontol Geriatr. 2013 Jan-Feb;56(1):265-9.

21. Vivanti AP, McDonald CK, Palmer MA, et al. Malnutrition associated with increased risk of frail mechanical falls among older people presenting to an emergency department. Emerg Med Australas. 2009 Oct;21(5):386-94.

22. Jacob Filho W. Fatores determinantes do envelhecimento saudável. Bol. Inst. Saúde. 2009 Apr;47:27-32.

23. Sim M, Blekkenhorst LC, Lewis JR, et al. Vegetable diversity, injurious falls, and fracture risk in older women: a prospective cohort study. Nutrients. 2018 Aug;10(8):1081.

24. Santos AL, Cecílio HPM, Teston EF, et al. Complicações microvasculares em diabéticos tipo 2 e fatores associados: inquérito telefônico de morbidade autorreferida. Cienc. Saúde Coletiva. 2015 Mar;20(3):761-70

25. Universidade Federal de Minas Gerais. Faculdade de Farmácia. Aspectos clínicos e epidemiológicos de pacientes submetidos à avaliação osteometabólica no Centro Mais Vida (CMV) do Instituto Jenny Faria de Atenção à Saúde do Idoso e da Mulher. Base de dados. 2016. 